\title{
Entrepreneurial opportunity decisions under uncertainty: Recognizing the complementing role of personality traits and cognitive skills
}

\author{
Emmanuel Kwasi Mensah ${ }^{1}$ iD, Lawrence Adu \\ Asamoah $^{2}$ (iD, and Vahid Jafari-Sadeghi*
}

\begin{abstract}
Purpose: The aim of this paper focuses on advancing the entrepreneurial literature by enhancing the understanding of the connections between personal behavior and cognitive skills in decision making under uncertainty. Methodology: The method of this research has been adapted the framework used by Garrett and Holland (2015), who developed propositions from the conceptual narratives of how environmental uncertainty and complexity differentially affect the motivations and cognition of independent entrepreneurs and corporate entrepreneurs to engage in entrepreneurial action. Findings: The findings of this research provide a conceptual basis for a broader perspective on behaviors and cognitions that motivate or hinder entrepreneurial actions while at the same time, positioning the entrepreneur's decision at the core of decision theory. Implications for theory and practice: Theoretically, this research contributes to a holistic view of opportunity decisions. It redirects the traditional analyses path of entrepreneurial decisions discussed distinctively from the personal behavior or cognition paradigm, which does not provide a complete view into the larger entrepreneurial decisions under uncertainty. Practically, our argument provides further insight into the black box of entrepreneurial opportunity decisions under uncertainty and thus highlights the need for a broader perspective for the entrepreneur, especially in the early stage of venture formation, where some cognitions and required personal attributes are needed in consonance for entrepreneurial action. Originality and value: Entrepreneurship research on

1 Emmanuel Kwasi Mensah, Ph.D., Department of Economics, Via Ravasi, 2, 21100 Varese VA, University of Insubria, Varese, Italy, e-mail: ekmensah@uninsubria.it or kwasimensah87@gmail.com (ORCID: https://orcid.org/0000-0003-3337-0553). 2 Lawrence Adu Asamoah, Ph.D. candidate, Department of Economics, Via Ravasi, 2, 21100 Varese VA, University of Insubria, Varese, Italy, e-mail: laduasamoah@uninsubria.it (ORCID: https://orcid.org/0000-0002-3193-5875).

3 Vahid Jafari-Sadeghi, Ph.D., School of Strategy and Leadership, Coventry University, CV1 5FB Coventry, United Kingdom, e-mail: vahid.jafari-sadeghi@coventry.ac.uk (ORCID: https://orcid.org/000-0003-3083-6119). *(corresponding author)
\end{abstract}


decision making under uncertainty has mainly focused on the effect of uncertainty on entrepreneurial actions, while an attempt at the individual level, particularly, from the cognitive framework seeks to explain why actions differ. Scholarly efforts have also been made on what informs entrepreneurial actions from the perspective of the entrepreneur's personal attributes. However, no integrated approach is offered in the literature to study how cognitive skills and personality traits complement each other. Keywords: entrepreneurial opportunity, cognitive skills, personality traits, decision making under uncertainty, entrepreneurship research

\section{INTRODUCTION}

Entrepreneurial decisions on opportunities under uncertainty are at the core of entrepreneurship studies. The decision to discover or create opportunity, and the corresponding action to exploit them, drives market processes and the fulfillment of social and economic needs. In this regard, an entrepreneurial decision under uncertainty defines the boundary and exchange conditions under which individual decision may yield fulfilling outcomes (Short etal., 2010). The literature conveys different decision styles towards opportunity creation or recognition, which most crucially involve the nature of the entrepreneur and his cognition, and to a broader spectrum, the biological building block including genetic factors of the entrepreneur (Nicolaou \& Shane, 2010). Mostly, action taking under uncertainty encompasses personality traits or behavioral processes and cognitive skills as well as some heuristics. Cognitive processes that enable entrepreneurs to use simplifying mental models to unify previously unconnected information that help them to identify and explore opportunities have been a critical focal point in decision making. Heuristics and cognitive biases, albeit overconfidence and representativeness (Busenitz \& Barney, 1997; Kahneman \& Frederick, 2002), counterfactual thinking, affect infusion, alertness schema and pattern recognition (Baron 2004; Gaglio \& Katz, 2001), and effectuation process (Sarasvathy, 2001) have all been explored as probable strategies used by entrepreneurs to reach acceptable decisions. However, while much of the entrepreneurship literature had previously viewed opportunity as something enacted, thus suggesting personality traits (Short et al., 2010; Kerr, Kerr, \& Xu, 2018), and while a growing number of scholars in recent times view opportunity from the cognitive perspective, there seems to be a conspicuous lack of studies on the complementary role of these two pillars of the literature strands. In fact, the two combine, albeit other factors such as information corridors to demystify the understanding of why some people but not others decide to discover and profitably exploit opportunities (Shane \& Venkataraman, 2000). 
Recent constructs by McMullen and Shepherd (2006), which assessed the link between entrepreneur action and the role of uncertainty, reveal that the entrepreneur's perception of uncertainty and willingness to bear such uncertainty are the divisive components that separate the entrepreneur's actions from his inactions on entrepreneurial opportunities (Garrett \& Holland, 2015; Sadeghi, Biancone, Giacoma, \& Secinaro, 2018; McKelvie, Haynie, \& Gustavsson, 2011; McMullen \& Shepherd, 2006). Further, in analyzing the role of emotions on investment decision under uncertainty, Brundin \& Gustafsson (2013) demonstrated that emotions played a significant role in the entrepreneur's decisions to continue or discontinue investment under uncertainty. They noted that personal attributes such as self-confidence and hope magnify the entrepreneur's propensity to invest under high uncertainty, whereas frustration and embarrassment decrease the entrepreneur's predilection to invest in the presence of high uncertainty. In the same vein, Hansen et al. (2016) proposed a model that provided a unified account of different ideologies on opportunity discovery and creation, making it much easier to identify critical elements that matter for decision making on opportunity outcomes. Hansen et al. (2016) were only able to describe the effect of uncertainties as occurrences that are detrimental to the actions and subsequent decisions of the entrepreneur.

While the contributions of previous researchers have been profound to entrepreneurial research on attitudes and behavior, the synthesis between personality traits and cognitive skills remain scant for decision making under uncertainty. The 'why and how' certain actions are taken on opportunity decisions in an uncertain environment have been narrowly discussed to bring a profound generalization of the issue. We address this gap by studying the complementary relationship between personality traits - self-confidence, ambiguity aversion, locus of control, and cognitive skills - alertness to schema, tacit knowledge, counterfactual thinking, while addressing distinctively the implication of each on opportunity decisions under uncertainty. To the best of our knowledge, this paper is among the only few, if there is, which situate entrepreneurial opportunity recognition or creation in the context of decision making under uncertainty.

To sum it up, the objective of this paper focuses on advancing the entrepreneurial literature by enhancing the understanding of the connections between personal behavior and cognitive skills in decision making under uncertainty. While prior studies focused on the implications of the cognition and individual personality attributes of the entrepreneur, less emphasis has been made on the relationships between cognitive skills and personality attributes. Curious questions are the following: do some entrepreneurs use cognitive skills differently and do those skills lead to opportunity 
decisions through enhancing their personality traits? More specifically, are the personality traits of the individual differently influenced by how well their cognitive skills are best put to use in an unexpected environment? For instance, will the ambiguity-averse entrepreneur be more alert to opportunity discovery when he has developed his alertness to the schema? On the other hand, will a poor cognitive skilled individual be able to decide on opportunities in time if such an individual possesses good personal attributes to achieve entrepreneurial success as put forward by McClelland (1987)? Developing propositions to argue on these questions, we position ourselves to understand further the "why" and "how" questions (Simon, Houghton, \& Aquino, 2000; Baron, 2004) on how some individuals are able to recognize or create opportunities in a complex environment, while others are not able to, even in the light of high cognitive skills or strong personal attributes.

The next portion of this study is used to review themes on decision making under uncertainty. We review entrepreneurial uncertainty and argue that entrepreneurs are not bound to the strictly normative reasoning of the rational choice theorist or the prescriptive argument of the psychological and behavioral economist; instead, they switch on rationalities, using heuristics and biases built on their cognitive skills and personal attributes including available information to make opportunity decisions. This view motivates our contribution to the complementary role of personal and cognitive skills. The method used for this research is discussed in the next two sections. Finally, we engage in a discussion on the views expressed in this paper and make conclusions and suggestions for further research in the future.

\section{LITERATURE REVIEW}

To position the entrepreneur's decision at the center of the decision theory, we focus on the review of distinct streams of the literature on decision making under uncertainty. We build on the following strands of the literature: (1) entrepreneurial uncertainty; (2) rational choice theory; (3) bounded rationality-heuristics and biases; and (4) the role of information in uncertain decisions. The second strand provides the normative understanding of decisions under uncertainty from the economic perspective (Savage, 1954; Scott, 2000), while the third strand describes the prescriptive reasoning from the psychological and behavioral economist perspective (Simon, 1957; Kahneman \& Tversky, 1979; Gustafsson, 2009). Thus, the review here draws some understanding from not only the historical antecedent of decision making under uncertainty but also how the entrepreneurial decisions differ from some psycho-economic theories of decisions under uncertainty. 


\section{Entrepreneurial uncertainty}

Knight's (1921) work on risk, uncertainty, and profit describes risk as a situation or game that can be known with certainty through measurable probability, whereas it describes uncertainty as having no measurable probability or likelihood of occurrence. The former depicts some degree of uncertainty that is quantifiable and can be avoided by the entrepreneur, making adjustments to reduce his exposure to it. By Knight's reasoning, only the latter rather than the former is essential in explaining the nature of competition and profit. Besides, only through it can it be possible for entrepreneurs to supersede the normal returns associated with equilibrium in competitive markets. Because entrepreneurs cannot prevent uncertainty, neither can they insure against it, and they are characterized by their aversion or tolerance towards it (Amit et al., 1993). Moreover, the uncertainty type manifested eventually determines the entrepreneur's actions and decision policy (Milliken, 1987; McKelvie et al., 2011). Brundin and Gustafsson (2013) show that entrepreneurs attach different attitude to different uncertainty levels with regards to decision making. The uncertainty can be perceived as mild, severe or absolute depending on the available information. Mild uncertainties may pose intangible effects on the decisions of the entrepreneur and hence, manageable. However, severe uncertainties may create difficult situations for the entrepreneur in discriminating between relevant and irrelevant information in the presence of a foreseeable opportunity.

As noted in McKelvie et al. (2011), the specific kind of entrepreneurial actions, however, may depend on the nature of uncertainty, mostly influenced by the level of information asymmetry (Petrakis \& Konstantakopoulou, 2015). In regard to the fact that the entrepreneur bears the sole responsibility for unmasking the uncertainty towards making such pertinent opportunity (McMullen \& Shepherd, 2006), understanding the nature of uncertainty presents ways to delineate them to match one's decision. In this sense, we can argue that the nature of uncertainty plays a significant role in entrepreneurial decisions. It is important to note that these uncertainties are moderated by the availability of information. Kirzner (1979) suggests that information asymmetry is the revolving factor to market disequilibrium and opportunity recognition, and complete knowledge about the environment balances entrepreneurial decisions. In most instances, the means of handling certain uncertainties using private information, tacit knowledge, and cognitive biases are treated as private resources by entrepreneurs to have a comparative advantage over competitors. 


\section{Rational choice theory}

The normative reasoning implied by the rational choice theorists follows the idea that all human actions are rational in character and motivated by want or goals that give optimal satisfaction. Individual decisions must be optimal, decisions ought to follow certain mathematical axioms to be rational; individuals are portrayed as economic agents who are fully 'rational minimizers' of subjective utility (Gigerenzer \& Selten, 2002; Boudlaie et al., 2020). The rational choice theory attempts to explain decision behavior according to the assumption of utility maximization based on a selfish or altruistic preference (Neumann \& Morgenstern, 1944; Scott, 2000; Moscati \& Tubaro, 2011) while its theorists hold the view that people evaluate risky and uncertain prospects by comparing their expected utility values. One of the popularly used, yet well criticized for its non-practical axiomatization in human decisions, is the Subjective Expected Utility (SEU) popularized by Savage (1954). Savage's SEU describes how individuals make decisions under uncertainty in a fascinating way by reducing the whole decision spectrum into a common set of primitives; probability, utility, and options (Fischhoff, Goitein, \& Shapira 1981). Under these primitives, the individual has the option to assign a probability of desirable outcomes (utilities) before making decisions. In other words, individuals are considered as identifying an alternative course of actions, anticipating their outcomes, and calculating that which is best for them. Rational individuals select the optimum alternative that gives the best satisfaction (Scott 2000). See also Mensah (2019) on how some mathematical approaches are used for decision making under uncertainty.

Nonetheless, such rationality is largely incompatible with the kind of information, the computational capabilities of the individual, and the environment (Simon, 1957; Gigerenzer \& Selten, 2002). As contended in literature from the behavioral economists and entrepreneurial point of view, people behave in the context of complex social phenomena and an uncertain environment can be rational or irrational. These environmental uncertainties are defined as the lack of ability to properly envision the probable outcomes of a decision (Jafari-Sadeghi et al., 2019; McKelvie et al., 2011; Mokhtarzadeh et al., 2020; Smithson, 2012). Although a stream of research (see Downey \& Slocum, 1975; Smithson, 2012) refers environmental uncertainties to the lack of predicting the likelihood of future events, others, e.g. Milliken (1987), point to the lack of information about cause-effect relationships (Milliken, 1987). Behaviors are perceived to be random in nature and diverge from rational choice theory more radically (Moscati \& Tubaro 2011). As a result, the rational choice theory may not conform to the random behaviors of people in general when presented with uncertain choices. For instance, 
Ellsberg's famous paradox demonstrates that decision makers and investors faced with uncertainty may not make choices consistent with the SEU but with ambiguity aversion to choices whose likelihood they have confidence in. In the entrepreneurship literature, the view is quite different. The conventional framing of rationality applies perhaps to opportunity discovery, since opportunity discovery calls for rationality that informs the search process - discovery, evaluation, and exploitation - that presents an expected outcome on the opportunity (Kirzner 1997). Miller's (2007) studies show that on the contrary, such rationality may be counterintuitive to opportunity recognition and discovery. This is because entrepreneurs engage in the distinct entrepreneurial process and the concept of rationality, if any fails to be characterized with the creative process of the entrepreneur. Recounting further from Knight's experience on rationality, which of course is different from the rational choice theorist view, a rational response to uncertainty may be to reduce it to risk if it is not possible to avoid. In this framework, rather than one focusing only on market profit, an effectuation logic must be applied, along this line, by making decisions based on affordable loss or acceptable risk (Sarasvathy, 2001).

Effectuation literature has been constructed to explain how entrepreneurs deal with uncertain environments (Welter \& Kim, 2018) and how entrepreneurs handle uncertainties by taking advantage of various predictive and controlling strategies. In her theory, Sarasvathy (2001) shows that under conditions of uncertainty, entrepreneurs adopt a decision logic that is different from the one explicated by a traditional entrepreneurship model and rational choice theory. The entrepreneur exerts control over the available set of means which s/he has control over, such as personal knowledge, skills, social networks, etc., instead of focusing on goals (Gilbert-Saad, Siedlok \& McNaughton 2018; Rezaei et al., 2020). As noted in Perry, Chandler and Markova (2012), the flexibilities of the effectuation logic allow individuals to take advantage of environmental contingencies as they arise and to learn as the firm grows. This said, as emphasized in Nielsen and Lassen (2012), the effectual logic is likely to be more effective in settings characterized by greater levels of uncertainty, particularly in the context of new businesses. Sarasvathy (2008) shows that effectual logic is predominantly used in the earlier stages of venture creation with a transition to more causal strategies as the new firm and market emerge out of uncertainty into a more predictable situation.

In summary, considering the complexity of the entrepreneurial process, although the construct of identity has predominantly been theorized based on the assumptions of neoclassical economics of rational choice, which assume causal effects when individuals pursue entrepreneurial opportunities, recent 
argument differs. As with the satisfying theory of Simon and the effectuation theory of Sarasvathy, entrepreneurs employ effectuation logic (which includes the necessary heuristic activities), including cognitive biases when pursuing entrepreneurial opportunities in uncertain situations.

\section{Bounded rationality: Heuristics and biases}

Because there are naturally no such unlimited human resources such as unlimited cognitive capabilities, unlimited information and unlimited time, 'heuristics and biases' instead make up a residual category for deviations from rationality as defined by the expected utility theory. According to Simon, an individual's cognitive abilities are limited, and so decision making becomes a search process that would lead to satisfactory result guided by aspirations (Simon, 1957; Gigerenzer \& Selten, 2002). Therefore, by arriving at such satisfying decisions, people are not seen as irrational but rationally bounded by the conditions in which they find themselves. Entrepreneurs particularly do not follow normative theories, as their preferences are highly inconsistent even in a situation involving no risk or uncertainty. In making decisions bounded by constraints, entrepreneurs use heuristics and biases based on their adaptation to experiences, skills, psychological plausibility, and the structure of the environment. Known as an adaptive toolbox, such tools consist of cognitive abilities - set of rules (search, stop, decide) and specific domain heuristics used in achieving proximal goals.

Heuristics and biases study how decision-makers, in this case, entrepreneurs, employ subjective opinions and cognitive mechanisms used in decision making, especially in a complex and uncertain environment. For instance, heuristics types such as availability, representativeness and base-rate fallacy, and illusion control (Kahneman \& Frederick 2002) are commonly used in literature and largely employed by entrepreneurs in decision making. Besides, people who are more prone to use heuristics and biases during the decision-making process because of the complexity of the decision environment are more likely to become entrepreneurs (Busenitz \& Barney, 1997). The heuristics and biases decision framework takes the SEU model of rationality as the counterfactual for comparison purposes, and stretches on the descriptive alternative-but not a normative alternative to decisions under uncertainty (Miller, 2007). While they are very useful to opportunity decisions, they are much dependent on the entrepreneur in question. Entrepreneurs with greater cognitive skills are more probable to construct cogent heuristics towards opportunity decisions than those with lower cognitive skills. In the sections that follow, we demonstrate how some personal behaviors and cognitive skills shape these heuristics and motivate 
or otherwise prevent the entrepreneur from making opportunity decisions in a complex environment.

\section{Role of information in uncertain decisions}

Shane \& Venkataraman (2000) assert that the information necessary to recognize opportunity is not evenly distributed because of its specialization in society. In their celebrated paper, they termed this as 'information corridors' in which human beings possess a different stock of information that influences their ability to recognize a certain kind of opportunity. The decision environment is thus affected by the availability of information, which explains how certain people are able to recognize opportunities that others cannot identify. Available information creates mental schemas, which provide a framework for recognizing new information that triggers an entrepreneurship conjecture (Shane \& Venkataraman, 2000; Koellinger et al., 2007). Entrepreneurs' tolerance for ambiguity, risk-taking propensity, confidence level, and confirmation bias are all contingent on the weight of evidence informed by the information at hand. Information asymmetry is important to the success of young entrepreneurs. Recent research on entrepreneurship has suggested that many entrepreneurs would change certain earlier decisions if they had had additional relevant information prior to their decision. For instance, for failed new venture owners who took risky action based on very limited information, overconfidence and illusion control (Jafari-Sadeghi et al., 2020; Zacharakis \& Shepherd, 2001; Koellinger, Minniti, \& Schade, 2007), additional and relevant information might have saved their short-span failed ventures (Simon, Houghton, \& Aquino, 2000).

Because uncertainty is characterized by unknown or limited information, the entrepreneur is unable to anticipate any changes in the environment from which opportunities are generated (McKelvie et al., 2011; Milliken, 1987). However, since uncertainty is the main construct under which innovation, profit, market equilibrium and allocation of resources are made, information discovery and processing become an important concept in the creation of opportunities (Amit et al. 1993; Kirzner 1979; Knight 1921). As noted by Kirzner (1979), information asymmetry is the revolving factor to market disequilibrium and opportunity recognition. In this sense, information asymmetry forms the synthetic barrier between rational theorist decisions, which assume full access to information, and entrepreneurial decisions. While the former is constructive and formalized on probabilities deduced from the given information, the latter is heuristically indeterminate. 


\section{RESEARCH METHODS}

Our primary purpose is to identify some personality traits, also referred to as behavioral and cognitive skills, which entrepreneurs use in their opportunity decisions under uncertainty, and further examine the complementary role that these two pillars in the entrepreneurship research have on each other. We adapted the framework used by Garrett and Holland (2015), who developed propositions from the conceptual narratives of how environmental uncertainty and complexity differentially affect the motivations and cognition of independent entrepreneurs and corporate entrepreneurs to engage in entrepreneurial action. Taking advantage of the existing research findings and a state-of-the-art literature review, we construct a theoretical framework via propositions to explain how the creation or discovery of opportunity under uncertainty is affected by traits and skills and why recognizing the complementing role of the two is crucial for the entrepreneur's decisions.

To provide a complete overview of the entrepreneurial decisions under uncertainty, we began with the basic concepts of uncertainty in entrepreneurial decisions and its antecedents from the literature, encompassing psychoeconomic theories. Decisions under uncertainty that follow the normative and prescriptive reasoning of the rational theorist and behavioral economist yield optimal decisions and satisfying decisions. However, they are rarely what entrepreneurs rely on to make decisions on the opportunity. In this regard, the goal of the literature review was to explain how those psycho-economic theories differ from the former's approach. Moreover, since the main goal of this paper, in analyzing the entrepreneurial opportunity decisions under uncertainty, is to identify the complementing role of personality traits and cognitive skills distinctively discussed across the literature, a conceptual model, which divides into personality traits and cognitive processes, is adopted as the framework from which propositions are developed.

Across the literature, a different number of elements under these two strands are discussed (e.g., McMullen and Shepherd, 2006; Short et al., 2010; Shane \& Venkataraman, 2000; Hansen et al., 2016). For instance, typical elements in the cognitive processes category include overconfidence and representativeness (Busenitz \& Barney, 1997; Kahneman \& Frederick, 2002), counterfactual thinking, affect infusion, alertness schema and pattern recognition (Baron, 2004; Gaglio \& Katz, 2001), and effectuation process (Sarasvathy, 2001), which are all suggested as simple strategies used to reach acceptable decisions. On the other hand, elements in the personality traits category involve a person-opportunity nexus (Shane \& Venkataraman, 2000) and they include self-confidence, hope, and emotions (Brundin \& Gustafsson, 2013), self-efficacy and innovativeness, the need for achievement 
(Kerr et al., 2018) and ambiguity seeking (Eichberger et al., 2012; Sukumar et al., 2020) among others. Although there are dozens of these traits and skills of the entrepreneur discussed in the literature, this paper focused on the main cognitive skills and personality traits that are most essential for decisions on opportunity discovery and creation. Figure 1 illustrates the conceptual model used. The model samples three main elements of personality traits: selfconfidence, ambiguity aversion, and locus control; and cognitive skills: alertness to schema, tacit knowledge, and counterfactual thinking. It is important to focus on just these few because this study is to determine how these traits and skills complement each other in an uncertain environment. The research papers selected for this study, therefore, focused on the main theme. Papers, which drew attention to entrepreneurial decisions and the broader decision theory - past and old, were used to solicit for the vital view that could be used to build an argument. Because many of our strong arguments needed papers that were published in peer-reviewed journals, we did not include papers that were not peer-reviewed even though some were useful.

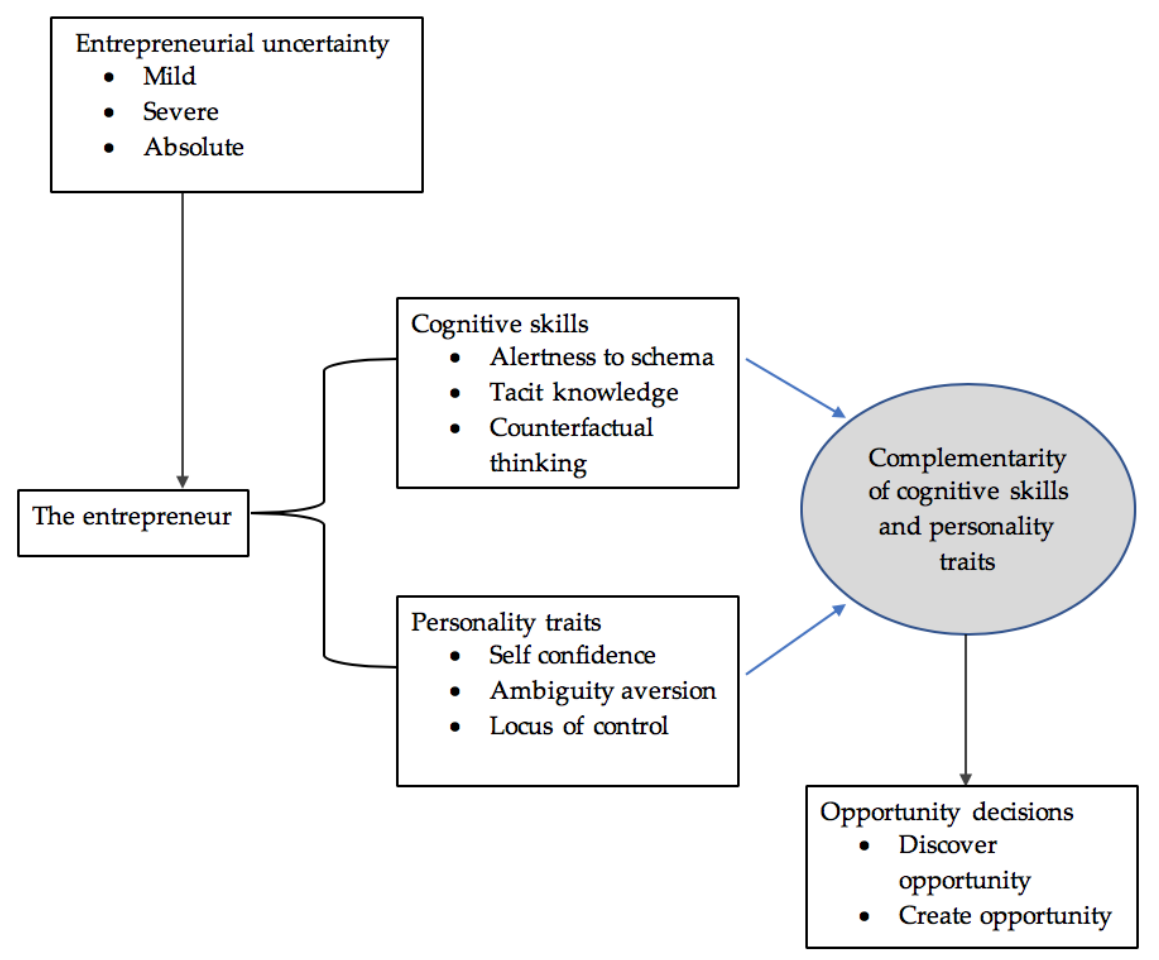

Figure 1. Conceptual model 


\section{PROPOSITIONS}

\section{Personality traits and cognitive skills in entrepreneur decisions under uncertainty}

Until recently, prior studies have presented entrepreneurial personality as the key component of new venture formation and the reason for diverse decisions on opportunities (Shane \& Venkataraman, 2000; Mitchell et al., 2002; Sadeghi \& Biancone, 2017a). As the unique set of personality traits and differences in psychological and demographic characteristics became difficult to comprehend, studies on decision making shifted focus towards the epistemological difference, informational access, and environmental complexities of the entrepreneur. Most of these studies have particularly focused on the cognitive skills of the entrepreneur (Baron, 2004; Busenitz \& Barney, 1997; Gaglio \& Katz, 2001; Simon et al., 2000). Notwithstanding, who an entrepreneur is, what defines and drives them, and how they manage what they do requires an unblemished analysis of the past and recent views of the entrepreneurial opportunity decisions. In this paper, we mostly focus our discussion on personality traits and cognitive skills that present the entrepreneur with simple mental models towards decision making under uncertainty. In this paper, we argue that the broad discussion should be focused on the complementing role of traits and skills towards the decisions on an opportunity of the entrepreneur rather than a one-sided argument or a distinct view of the two.

\section{Personality traits towards opportunity decisions under uncertainty}

\section{Self-confidence}

In his article titled "Characteristics of successful entrepreneurs," McClelland (1987) employs a critical realist perspective to understand the personality traits of successful entrepreneurs. His observation demonstrates that selfconfidence is among the competencies and principal characteristics of successful entrepreneurs. This provided a helpful understanding of the way personality traits such as one's self-confidence contribute to entrepreneurial decision making under uncertainty. The support for this positive relationship is strong both theoretically and empirically. For instance, Schumpeter (1961) postulates that such motivation drives the will and actions of entrepreneurs to eventually overtake incumbent market leaders (in the sense of creative destruction). This notwithstanding, Bandura's (1997) theory of self-efficacy, which is rooted in social, behavioral theory, validates a positive association 
between self-confidence and entrepreneurial outcome through the thoughts and behavior of the entrepreneur. In a related theory, though not in the entrepreneurial field, Vealey (2001) found a positive relationship between self-confidence and sports performance. Although the majority of prior studies found support for this line of argument, there exist some notable exceptions, such as Zacharakis and Shepherd (2001), and Koellinger et al. (2007), who found a negative association between self-confidence and performance. One possible explanation for such findings is that high confidence can lead to risk-taking and/or complacency, which in turn may impede an entrepreneurial decision under uncertainty. However, McMullen and Shepherd (2006) emphasize that if the entrepreneur is pushed by his self-confidence to overcome his doubt beyond a potential cost envisaged, then the entrepreneur's actions will be actualized. Thus, we propose that:

Proposition 1: A higher self-confidence or self-efficacy of the entrepreneur will drive the willingness to bear uncertainty and make uncertain decisions on opportunities.

Regarding this proposition 1, there is the need to draw a thin line between known self-confidence and over-confidence as a prudent measure to avoid inaccurate decisions. Although entrepreneurial confidence is desirable, overconfidence, on the other hand, creates a bias that affects the accuracy of decisions (Busenitz \& Barney, 1997; Koellinger et al., 2007; Zacharakis \& Shepherd, 2001). Usually, for novice entrepreneurs and new venture founders, overconfidence is pervasive; inaccurate market predictions and perception failures are highly probable. They either show optimistic overconfidence or an overestimation of their own knowledge (Busenitz \& Barney, 1997; Zacharakis \& Shepherd, 2001) and apparently reduce the need for thorough information required for decisions under uncertainty. Overconfidence is associated with lower metacognitive ability and positive illusions that undermine the detailed process in decision making, resulting in inaccuracies and poor result.

\section{Ambiguity aversion}

Entrepreneurs are predisposed to uncertainty in which they have to make judgments about a future they do not have control of. Relative to selfconfidence and entrepreneur's choices to success, prior studies emphasize that entrepreneurs often are faced with an ambiguous future that limits them from exploiting foreseeable opportunities under probabilistic judgments (Eichberger et al., 2012). In this way, ambiguity aversion, rather than risk aversion, becomes the main inhibitor of entrepreneur opportunity creation (Knight, 1921; Amit et 
al., 1993). Generally, ambiguity aversion can be an inherent character of the individual, which may be invariant with the information required for decision making. For instance, an entrepreneur's willingness to start a business may entail ambiguity judgments in which information about the future is often incomplete. If the entrepreneur were to wait for such additional information to increase the success of the foreseeable opportunity, the opportunity would have passed (Simon \& Houghton, 2003; Ng, 2013).

Proposition 2: A high ambiguity aversion towards opportunity in a complex environment will deter entrepreneurial decision on the opportunity.

A degree of belief informs the entrepreneur's perception and psychological aspect of judgment. Subjective judgment formed as a response to an ambiguous future, following inadequate information or environment, can worsen the entrepreneur's tolerance towards ambiguity. In such an instance, an unwillingness to act and make decisions in the face of uncertainty can discourage entrepreneurs from certain opportunity discovery and creation (Bhidé, 2000).

Sarasvathy (2001) contends that entrepreneurs often have to undertake economic decisions in which the success of the future of their businesses are dependent on leveraging the firm's internal resources with the resources of external stakeholders (Harvey, $\mathrm{Ng}$, \& Klein, 2015). Notwithstanding, such complexities in the presence of limited resources increase the difficulties of assigning causes of success and failure, and since the establishment of cause and effect can present difficult situations to the entrepreneur, finding an associated source of performance may be highly ambiguous, in which impreciseness may be eminent in the entrepreneur's decisions (Ng, 2015). An ambiguity seeking entrepreneur may see ambiguity as an opportunity rather than a threat and such a view of uncertainty, according to Begley and Boyd (1987), may indicate a positive relationship with the financial performance of the venture. For instance, experienced entrepreneurs may draw on existing knowledge to evaluate the ambiguity surrounding the future prospects of their businesses (Sadeghi \& Biancone, 2017b). This is because experienced entrepreneurs exhibit greater knowledge of the causes underlying their subjective probabilities and they may place greater emphasis on their subjective view of the opportunity, not only because of its probabilistic success but because they have their previous experiences bound to the subjective views (Jafari Sadeghi, Kimiagari, \& Biancone, 2020). Thus, experienced entrepreneurs tend to act on their own personal judgments rather than consulting on objective probability judgment, which they may perceive as unreliable (Dew, Read, Sarasvathy, \& Wiltbank, 2009). The 
implication of this complexity demonstrates that when making judgments to exploit opportunities, causal ambiguities may play a significant role in undermining the belief held in one's probabilistic judgments.

\section{Locus of control}

Locus of control is a very important personality trait in shaping how an individual perceives the environment. It relates to the generalized belief that the outcome of an action is contingent on one's own behavior or the outcome is a function of external forces or environmental features that cannot be influenced (Rotter, 1990; Kerr et al., 2018). Both internal and external locus of control exists to characterize people on entrepreneurial opportunity decisions under uncertainty. People with an internal locus of control believe that event in their lives, both achieving success or avoiding failure on new ventures, are due to their own decisions, efforts, or action. They, therefore, show capabilities, willingness to learn, and pursue courses that will enhance their knowledge to influence the outcome of their environment (Asante \& Affum-Osei, 2019; Garousi Mokhtarzadeh et al., 2020). In contrast, people with an external locus of control find the success of a new venture to be the result of uncontrollable forces (Yan, 2018; Kerr et al., 2018). They perceive an event in life as the outcome of luck or chance and, hence, their ability to discover opportunities may be impeded by their belief in luck rather than effort (Asante \& Affum-Osei, 2019). An in-depth examination of the entrepreneurship literature has identified the locus of control, internally, as one of the most dominant entrepreneurial characteristics and one that is a predictor of entrepreneurial intentions. People with a high level of perceived internal locus of control have been associated with entrepreneurial behavior and a preference for innovative strategies amidst complex environment, while people with an external or low internal locus of control are perceived as having a conservative behavior in relation to the creation of new business ventures (Wijbenga $\&$ van Witteloostuijn, 2007).

Studies have shown that the founders of new businesses have a more internal locus of control than owners who were not involved in a start-up (Begley \& Boyd, 1987; Yan, 2018). In their meta-analysis, (Rauch \& Frese, 2007) concluded that an internal locus of control has a significant correlation with opportunity creation and the successful exploitation of the opportunity. An earlier study by Gürol and Atsan (2006) among university students, also found that students who are entrepreneurially inclined have an internal locus of control and a higher need for achievement and innovativeness than students who are not entrepreneurially inclined. Across the literature, an internal locus of control is thus observed to have motivational inclinations that make 
entrepreneurs more proactive and alert to entrepreneurial opportunities. In contrast, a low internal locus control tends to be more passive. The support for this claim is given in Wijbenga and van Witteloostuijn (2007), where it is hypothesized that an external locus of control in the dynamic environment has a low degree of adaptiveness or responsiveness to environmental contingencies. It follows then that this belief makes them prefer low-cost strategies to business innovations. In simple terms, they fail to believe that they may be able to control business outcomes and actively change their environment (Rauch \& Frese, 2007; Asante \& Affum-Osei, 2019), which implies their failure to recognize opportunity even when it is obvious. The ability to induce a decision on a new venture and take full control and responsibility for the business's outcome, however, requires an entrepreneur who has a higher internal locus of control and a more positive attitude for opportunity creating. Thus, we summarize with the proposition that:

Proposition 3: A higher internal locus of control will have a strong impact on the entrepreneur's perceptions on (new) opportunity discovery or creation.

\section{Cognitive skills towards uncertain decisions}

\section{Alertness to schema}

A schema is a cognitive structure of an evolving mental model that guides the individual in the reasoning and processing of information for a specific task (Gaglio \& Katz, 2001). They could be mental mode constructs on market price differentials for which sensitivity and alertness could generate a pure arbitrage opportunity. Such schemas can be role defined or event defined, and they demonstrate high performance and opportunity recognition by entrepreneurs who adopt them compared to those who do not (Baron, 2004; Garrett \& Holland, 2015). Entrepreneurial alertness, in line with schema, refers to an attitude of receptiveness to overlooked opportunities (Kirzner, 2009). In this regard, complex schema structures interlinking each other provide the entrepreneur with a projected view of environmental changes and quick corrections to any deviation from known patterns. On this, we could postulate that sensitivity to the schema will lead to a higher propensity to opportunity discovery.

Proposition 4: Entrepreneurs who are sensitive to key characteristics of their schema will have a higher propensity to opportunity discovery and quicker ways to decisions under uncertainty than those who are not. 
Alert entrepreneurs prompted by schema can reassess and react to changes in the environment so easily, especially when seemingly unrelated changes in the external environment do not correspond to the current schema. Sensitivity and habitual activation of the schema can lead to the chronic schema (Gaglio \& Katz, 2001), a situation which automates individuals to notice, without searching, opportunities, and market disequilibria. McMullen and Shepherd (2006) contend that cognitive and subjective differences between individuals allow some to have a more accurate projected view of changes in reality than others, and as a result, only such personalities can take appropriate entrepreneurial actions to correct deviations from known patterns within that reality. According to Valliere (2013), such entrepreneurial alertness can be said to arise from epistemological differences, where only some individuals know what to do. In this sense, the entrepreneur can make reasonable predictions of the future to plan new business moves to his advantage. For instance, successful product innovations are based on an entrepreneur's ability to recognize and develop new or unique resource combinations. Since alertness favors an intuitive decision process, an entrepreneur's mental schema enables him to develop a detailed understanding of the unique ways in which the business's resources can be combined to achieve a greater outcome ( $\mathrm{Ng}, 2015)$. It is roughly the case that entrepreneurs who are more likely to recognize patterns among a system of relationships and schemas are usually those who discover opportunities. This is also mostly the phenomenon seen with experienced entrepreneurs, since their experiences and developed schema offer a more nuanced understanding of their decision settings, than in the case of novice entrepreneurs (Baron \& Ensley, 2006).

\section{Tacit knowledge}

One of the greatest assets of the entrepreneur is his tacit knowledge formed through past experiences and the logical understanding of related patterns of events in the past. Tacit knowledge identifies the entrepreneur with a set of epistemic tools under which coherent decisions can be made. Though the concept of tacit knowledge is difficult to visualize or parametrize given its subjective, personal and idiosyncratic nature, it is known to demystify future circumstances and induce information search regarding the decision to create or recognize the opportunity. When the decision environment is varied with different degree of uncertainties and a lack of information, tacit knowledge provides an intuitive judgment on what actions must be taken (Ancori, Bureth, \& Cohendet, 2000). From the cognitive point of view, the entrepreneur's knowledge forms the basis for most of the biases made in uncertain decisions. Tacit awareness connects to the uncertain 
external environment and induces a construct for schemata, alertness, and meaningful patterns for the recognition of opportunities (McMullen \& Shepherd, 2006; Kirzner, 2009). Johnson and Bock (2017) demonstrate that the formation of tacit knowledge over time results from accumulated prior knowledge, which becomes valuable to the entrepreneur in making sense of the uncertainty in the environment. Prior studies, including Khatri and $\mathrm{Ng}$ (2000), and Baron and Ensley (2006), also conclude that entrepreneurs who employ tacit knowledge are "mentally richer" in identifying and further deciding on opportunities, whereas novice entrepreneurs may be denied those opportunities under uncertainty. To this end, the following proposition is clear to the concept of tacit knowledge:

Proposition 5: Entrepreneurs who possess tacit knowledge that codifies into information will be 'richer' in recognizing an opportunity and deciding on opportunity creation.

\section{Counterfactual thinking}

Counterfactual thinking is a cognitive skill that opportunity-seeking entrepreneurs engage in when confronted with a surprising or uncertain environment. It involves useful heuristics for developing educated guesses on the contrary to existing facts (Gaglio, 2004) and comparison of actual events to "alternatives that are constructed ad hoc rather than retrieved from past experience" (Kahneman \& Miller, 1986, Arora et al., 2013). The imagination of 'what might have been,' reflecting on alternative outcomes if the individual in question has taken different actions, can produce a mixed pattern of both potentially beneficial and harmful effects (Roese, 1997; Baron, 2000). Individuals engaging in counterfactual thinking usually focus on imagined outcomes that are better than those they achieved, which produces a feeling of regret. While this may be the case, as discussed in the cognition theory elsewhere (Landman et al., 1995; Roese, 1997), the reverse implication is pervasive in the entrepreneurial literature due to its importance with respect to the process of causal inference-efforts (Baron, 2000; Gaglio, 2004)).

A positive emotional experience (Landman et al., 1995), resulting from the relevant counterfactual thinking, could result in new venture creation and strike a difference between entrepreneurs and non-entrepreneurs (Baron, 2000). Thus, we hypothesize that the relevant counterfactual thinking will lead to opportunity discovery. 
Proposition 6: The relevant counterfactual thinking engaged in by the entrepreneur will have a causal consequence on opportunity creation than those who do not.

While we propose that counterfactual thinking will lead to the creation of new entrepreneurial opportunities through a positive emotional experience, we are most interested in how opportunity finders use counterfactual thinking. To examine this, we turn to use the argument established by Gaglio (2004) and Baron (2004). Baron (2004), in particular, argues that entrepreneurs are less likely than others in counterfactual thinking, since they may want to reflect on the future-oriented perspective than engage in past guilt. This notwithstanding, using a sequence of propositions, Gaglio (2004) proposed that the mental simulation and counterfactual thinking of the entrepreneur are a mechanism through which entrepreneurs identify and develop innovative opportunities. Because counterfactual thinking is involved in the evaluation of the pursuit of goals, entrepreneurs are able to use it to construct models that correspond to conjecture and into the identification and discovery of opportunities. In a recent study, Karim (2017) found counterfactual thinking influences opportunity identification in entrepreneurial career intention. As further propounded by Gaglio (2004), opportunity finders generate forward counterfactuals based on maintaining the unusual or unexpected event's, whereas non-finders do not. It follows closely from Kirzner's view, that alert individuals are those who use counterfactuals they construct in order, albeit with other mental mode constructs, to discover opportunities in unknown circumstances.

\section{Recognizing the complementarity of personality traits and cognitive skills}

Persisting research questions in entrepreneurship encompass how decisions on opportunities are made under a complex and changing environment. Specifically, why do some people but not others decide to discover and profitably exploit opportunities? Why do some people and not others succeed in new venture formation and why are some entrepreneurs more successful than others (Baron, 2004; Mitchell et al., 2002; Shane \& Venkataraman, 2000)? These questions underscore the differences among individuals in terms of their personality, biological make-up, and cognitive abilities. The general research on the collective understanding of the thinking process of the entrepreneur has gone beyond the single-insight individual paradigm to embrace access to information and cognitive abilities as the probable factors to discovering opportunities and partially answering the above-raised questions (Mitchell et al., 2002; Shane \& Venkataraman, 2000). 
Earlier on we made propositions that reiterate the role personal and cognitive skills play in the uncertain decisions on entrepreneurial opportunities. The importance of cognitive abilities emphasizes the significance of cognition as the divisive component to answering the 'why' and 'how' questions in the entrepreneurship decision process (Baron, 2004). It includes all the processes that are cognitive in nature, such as recognizing, problem-solving, or creative thinking, all of which take place within a person. The personal nature of the entrepreneur and his environment also represent an important understanding of 'why' certain decisions are made. These two complement each other in answering the 'how' and 'why' questions on opportunities under uncertainty. The significance of these bi-directional, complementing effects on entrepreneurial decisions under uncertainty are manifested through the following propositions: (1) personality traits are enhanced by cognitive abilities and, (2) cognition towards decisions is affected by personality traits. We argue these propositions below:

\section{Proposition 7: Personality traits are enhanced by cognitive abilities.}

In theorizing from the given propositions, it is easy to recognize that entrepreneurs who have developed their cognitive abilities are adequately prepared mentally in their personal pursuit of profit to make decisions in an uncertain environment. Additionally, their perception and opinions are more influenced towards a positive desire to explore an opportunity when cognition is utilized in the decision process. For instance, entrepreneurs rich in tacit knowledge are enhanced with a higher confidence to approach opportunities, whereas poor thinking and problem-solving skills contribute to negative outcomes. Previous scholars attribute a lower perception of risk and a personal decision to start new ventures to cognitive abilities and biases (Busenitz \& Barney, 1997; Simon et al., 2000; Biancone \& Jafari Sadeghi, 2016). At the broadest level, these cognitive abilities induce a sense of capabilities - a personal enhancement to pursue opportunities. Cognition plays a central role in self-efficacy, self-confidence, and self-motivation. For example, tacit knowledge and entrepreneur alertness can induce an appreciable level of self-confidence needed to embrace decisions under uncertainty. There have been studies showing a positive correlation between cognitive abilities and personality traits, notably the five-factor model (Tuten et al., 2001; Rammstedt et al., 2016), and between personality and entrepreneurial outcomes (McClelland, 1987; Murnieks et al., 2015), which enhances the argument of the role cognition plays in the development of some notable personality traits of the individual. 
Proposition 8: Cognition towards decisions is affected by personality traits.

Across the breadth of literature on psychology and organizational behavior, personality has been demonstrated to have an influence on several factors germane to prudent decisions (Baron, 2008; Rammstedt et al., 2016). The existence of the ability to construct schema and be alerted to it, combine tasks, and evaluate decisions on opportunities can be understood to be the consequence of a moral firm and knowledgeable entrepreneur. The study of Rammstedt et al. (2016) established education as the correlation between cognitive abilities and one's openness as well as emotional stability. It is therefore agreed that personality traits are instrumental in the development of intellectual skills (Ackerman, 1996) and mental structures. The extent to which one develops alertness to the schema, for instance, depends on belief and perception of the world. Entrepreneurs who are highly ambiguity intolerant tend to relent on the effort to construct a schema for uncertain decisions. Such a negative view of uncertainty prevents broader cognition and heuristics to creativity and opportunity search. Furthermore, recent findings suggest that emotions, motivation, affect, self-confidence and fear can potentially override and "tip the balance towards specific decisions" when the environment is uncertain (Baron, 2008; Brundin \& Gustafsson, 2013; Dimov, 2007; Jafari-Sadeghi, 2020). Therefore, while the personality paradigm, in theory, maybe under-studied in recent works it is essential to cognition, the general entrepreneur behavior and decisions in an uncertain environment.

\section{DISCUSSION AND CONCLUSION}

The central task of entrepreneurship is the willingness to act on economic decisions using information with or without certainty. In real-world entrepreneurial decisions, entrepreneurs with balanced personality traits and cognitive skills have been found to invariably exhibit success in their own ventures (McMullen \& Shepherd, 2006; Garrett \& Holland, 2015; Hansen et al., 2016). Yet, few entrepreneurial studies have advanced the literature on the dual complementing role of personality traits (Nawaz, Abbas Bhatti, Ahmad, \& Ahmed, 2018) and cognitive skills, examining them from the perspective of entrepreneurial behavior, identity, and context. The larger framework for decisions under uncertainty rests on the combination of personal behavior, sunk outcomes in committed ventures, the entrepreneur's cognitive skills, and the complexity of the environment. Besides, the contextual and social influences at a given time affect the decisions and the shaping of ideas of the entrepreneur (Dimov, 2007). This characterization of entrepreneurial 
personality traits and cognitive skills adds to the research on decisionmaking. In this study, we sought to achieve this by connecting personal traits with cognitive skills in their complementarity using some propositions to buttress our argument. In this regard, eight propositions are proposed in a framework that explores the integration between entrepreneurs' cognitive skills and personality traits in their discovery of business opportunities under uncertainty. This has some implications in both theory and practice.

Theoretically, our perspective contributes to a holistic view of opportunity decisions. It redirects the traditional analysis path of entrepreneurial decisions discussed distinctively from the personal behavior or cognition paradigm, which does not provide a complete view of the larger entrepreneurial decisions under uncertainty. We believe this a great step towards a finergrained typology of views, research, and teaching of opportunity discovery or creation in an uncertain environment. Additionally, we expect that analysis considering the complementary role of personal behavior or cognitive skills will further help to demystify the question of why and how some people but not others decide to discover and profitably exploit opportunities (Baron, 2004; Mitchell et al., 2002). Practically, our argument provides further insight into the black box of entrepreneurial opportunity decisions under uncertainty and thus highlights the need for a broader perspective for the entrepreneur, especially in the early stage of venture formation, where some cognitions and required personal attributes are needed in consonance for entrepreneurial action. This framework has implications for the characteristics of individuals planning to start a new business under the uncertainty. For instance, individuals with higher self-efficacy (personality traits) are seen as more willing to exploit business opportunities under uncertainty, as accurate decisions require a striking balance of how they are able to use some heuristics to further their cognition. We argue that, while objectively some gifted entrepreneurs may possess natural decision techniques, the ability to create certain opportunities under uncertainty relies largely on their trained cognitions and personal behavior.

We conclude by emphasizing that entrepreneurial opportunities are always marked by the understanding of personality traits and cognitive skills. Therefore, while there is a plentiful body of entrepreneurial literature on entrepreneurial behavior and cognitive skills, the discussion on the interplay between opportunity decisions must be recognized. We also propose that the framework of entrepreneurial decisions should be expanded to incorporate other symbolisms or identities that have a significant influence on the judgment of individual entrepreneurs, in order to increase our understanding. Future studies can examine the contribution of complexity and its associated biases in different types of entrepreneurial setting. Due to the presence of asymmetries 
in both aspects of the paternal and intergenerational family business, the inclusion of a dimension on complexity may increase our understanding of the biases that may influence the personality traits and cognitive skills of the entrepreneur in decision-making. Finally, while the arguments presented are intuitive, more empirical research on these propositions would enrich the entrepreneurship literature on decision making.

\section{References}

Ackerman, P. L. (1996). A theory of adult intellectual development: Process, personality, interests, and knowledge. Intelligence, 22(2), 227-257.

Amit, R., Glosten, L., \& Muller, E. (1993). Challenges to theory development in entrepreneurship research. Journal of Management Studies, 30(5), 815-834.

Ancori, B., Bureth, A., \& Cohendet, P. (2000). The economics of knowledge: The debate about codification and tacit knowledge. Industrial and Corporate Change, 9(2), 255-287.

Arora, P., Haynie, J. M., \& Laurence, G. A. (2013). Counterfactual thinking and entrepreneurial self-efficacy: The moderating role of self-esteem and dispositional affect. Entrepreneurship: Theory and Practice, 37(2), 359385. https://doi.org/10.1111/j.1540-6520.2011.00472.x

Asante, A. E., \& Affum-Osei, E. (2019). Entrepreneurship as a career choice: The impact of locus of control on aspiring entrepreneurs' opportunity recognition. Journal of Business Research, 98(February), 227-235. https://doi.org/10.1016/j.jbusres.2019.02.006

Bandura, A. (1997). Self-efficacy: The Exercise of Control. New York: Henry Holt \& Co.

Baron, R. A. (2000). Counterfactual thinking and venture formation: The potential effects of thinking about "what might have been." Journal of Business Venturing, 15(1), 79-91. https://doi.org/10.1016/S08839026(98)00024-X

Baron, R. A. (2004). The cognitive perspective: A valuable tool for answering entrepreneurship's basic "why" questions. Journal of Business Venturing, 19(2), 221-239.

Baron, R. A. (2008). The role of affect in the entrepreneurial process. Academy of Management Review, 33(2), 328-340.

Baron, R. A., \& Ensley, M. D. (2006). Opportunity recognition as the detection of meaningful patterns: Evidence from comparisons of novice and experienced entrepreneurs. Management Science, 52(9), 1331-1344.

Begley, T. M., \& Boyd, D. P. (1987). Psychological characteristics associated with performence in entrepreneurial firms and smaller businesses. Journal of Business Venturing, 2(1), 79-93.

Bhidé, A. V. (2000). The Origin and Evolution of New Businesses. Oxford: Oxford University Press. 
Biancone, P. Pietro, \& Jafari Sadeghi, V. (2016). Risk Management in export compliance: Concepts, procedures, and solutions. In V. Cantino, P. De Vincentiis, \& G. Racca (Eds.), Risk Management: Perspectives and Open Issues. A Multi-Disciplinary Approach (pp. 47-62). McGraw-Hill Education, London, UK. Retrieved from http://www.ateneonline.it/ cantino/ebook/

Boudlaie, H., Mahdiraji, H.A., Shamsi, S., Jafari-Sadeghi, V., \& GarciaPerez, A. (2020). Designing a human resource scorecard: An empirical stakeholder-based study with a company culture perspective. Journal of Entrepreneurship, Management and Innovation, 16(4), 113-147. https:// doi.org/10.7341/20201644

Brandstätter, H. (1997). Becoming an entrepreneur-a question of personality structure? Journal of Economic Psychology, 18(2-3), 157-177.

Brettel, M., Mauer, R., Engelen, A., \& Küpper, D. (2012). Corporate effectuation: Entrepreneurial action and its impact on R\&D project performance. Journal of Business Venturing, 27(2), 167-184. https://doi. org/10.1016/j.jbusvent.2011.01.001

Brundin, E., \& Gustafsson, V. (2013). Entrepreneurs' decision making under different levels of uncertainty: The role of emotions. International Journal of Entrepreneurial Behavior \& Research, 19(6), 568-591.

Busenitz, L. W., \& Barney, J. B. (1997). Differences between entrepreneurs and managers in large organizations: Biases and heuristics in strategic decision-making. Journal of Business Venturing, 12(1), 9-30.

Dew, N., Read, S., Sarasvathy, S. D., \& Wiltbank, R. (2009). Effectual versus predictive logics in entrepreneurial decision-making: Differences between experts and novices. Journal of Business Venturing, 24(4), 287-309.

Dimov, D. (2007). Beyond the single-person, single-insight attribution in understanding entrepreneurial opportunities. Entrepreneurship Theory and Practice, 31(5), 713-731.

Downey, H. K., \& Slocum, J. W. (1975). Uncertainty: Measures, research, and sources of variation. Academy of Management Journal, 18(3), 562-578.

Duncan, R. B. (1972). Characteristics of organizational environments and perceived environmental uncertainty. Administrative Science Quarterly, 313-327.

Eichberger, J., Grant, S., \& Kelsey, D. (2012). When is ambiguity--attitude constant? Journal of Risk and Uncertainty, 45(3), 239-263.

Ellsberg, D. (1961). Risk, ambiguity, and the Savage axioms. The Quarterly Journal of Economics, 643-669.

Fischhoff, B., Goitein, B., \& Shapira, Z. (1981). Subjective expected utility: A model of decision-making. Journal of the American Society for Information Science, 32(5), 391-399.

Gaglio, C. M. (2004). The role of mental simulations and counterfactual thinking in the opportunity identification process. Entrepreneurship Theory and Practice, 28(6), 533-552. 
Gaglio, C. M., \& Katz, J. A. (2001). The psychological basis of opportunity identification: Entrepreneurial alertness. Small Business Economics, 16(2), 95-111.

Garousi Mokhtarzadeh, N., Amoozad Mahdiraji, H., Jafarpanah, I., JafariSadeghi, V., \& Cardinali, S. (2020). Investigating the impact of networking capability on firm innovation performance: Using the resource-actionperformance framework. Journal of Intellectual Capital, 21(6), 10091034. https://doi.org/10.1108/JIC-01-2020-0005

Garrett, R. P., \& Holland, D. V. (2015). Environmental effects on the cognitions of corporate and independent entrepreneurs. Small Business Economics, 45(2), 369-381.

Gigerenzer, G., \& Selten, R. (2002). Bounded Rationality: The Adaptive Toolbox. Cambridge, Massachusetts: MIT Press.

Gilbert-Saad, A., Siedlok, F., \& McNaughton, R. B. (2018). Decision and design heuristics in the context of entrepreneurial uncertainties. Journal of Business Venturing Insights, 9, 75-80.

Gürol, Y., \& Atsan, N. (2006). Entrepreneurial characteristics amongst university students. Education + Training, 48(1), 25-38. https://doi. org/10.1108/00400910610645716

Gustafsson, V. (2009). Entrepreneurial decision-making: Thinking under uncertainty. In Understanding the Entrepreneurial Mind (pp. 285-304). Germany: Springer.

Hansen, D. J., Monllor, J., \& Shrader, R. C. (2016). Identifying the elements of entrepreneurial opportunity constructs: Recognizing what scholars are really examining. The International Journal of Entrepreneurship and Innovation, 17(4), 240-255.

Harvey, J., Ng, D. W., \& Klein, P. G. (2015). Complexity, novelty, and ethical judgment by entrepreneurs, 1-42. Retrieved from https://doi. org/10.2139/ssrn.2548773

Jafari-Sadeghi, V. (2020). The motivational factors of business venturing: Opportunity versus necessity? A gendered perspective on European countries. Journal of Business Research. 113(May 2020), 279-289. https://doi.org/10.1016/j.jbusres.2019.09.058

Jafari-Sadeghi, V., Kimiagari, S., \& Biancone, P. Pietro. (2020). Level of education and knowledge, foresight competency, and international entrepreneurship: A study of human capital determinants in the European countries. European Business Review, 32(1), 46-68. https:// doi.org/10.1108/EBR-05-2018-0098

Jafari-Sadeghi, V., Nkongolo-Bakenda, J-M., Dana, L-P., Anderson, R. B., \& Biancone, P. P. (2020). Home Country institutional context and entrepreneurial internationalization: The significance of human capital attributes. Journal of International Entrepreneurship, 2020(18), 165-195. https://doi.org/10.1007/s10843-019-00264-1

Jafari Sadeghi, V., Nkongolo-Bakenda, J-M., Anderson, R. B., \& Dana, L-P. (2019). An institution-based view of international entrepreneurship: 
A comparison of context-based and universal determinants in developing and economically advanced countries. International Business Review, 28(6), [101588]. https://doi.org/10.1016/j.ibusrev.2019.101588

Johnson, D., \& Bock, A. J. (2017). Coping with uncertainty: Entrepreneurial sensemaking in regenerative medicine venturing. The Journal of Technology Transfer, 42(1), 33-58.

Kahneman, D., \& Frederick, S. (2002). Representativeness revisited: Attribute substitution in intuitive judgment. Heuristics and Biases: The Psychology of Intuitive Judgment, 49, 81.

Kahneman, D., \& Miller, D. T. (1986). Norm theory. comparing reality to its alternatives. Psychological Review, 93(2), 136-153. https://doi. org/10.1037/0033-295X.93.2.136

Kahneman, D., \& Tversky, A. (1979). Prospect theory: An analysis of decision under risk. In Handbook of the fundamentals of Financial Decision Making: Part I (pp. 99-127). World Scientific.

Karim, M. S. (2017). Counterfactual thinking and entrepreneurial career intention. Academy of Management Proceedings, (1), 15900. https:// doi.org/10.5465/ambpp.2017.15900abstract

Kerr, S. P., Kerr, W. R., \& Xu, T. (2018). Personality traits of entrepreneurs: A review of recent literature. Foundations and Trends ${ }^{\circledR}$ in Entrepreneurship, 14(3), 279-356. https://doi.org/10.1561/0300000080

Khatri, N., \& Ng, H. A. (2000). The role of intuition in strategic decision making. Human Relations, 53(1), 57-86.

Kirzner, I. M. (1979). Perception, Opportuniy, and Profit. Chicago: University of Chicago Press

Kirzner, I. M. (1985). Discovery and the Capialist Process. Chicago: University of Chicago Press.

Kirzner, I. M. (2009). The alert and creative entrepreneur: A clarification. Small Business Economics, 32(2), 145-152. https://doi.org/10.1007/ s11187-008-9153-7

Knight, F. H. (1921). Risk, Uncertainty and Profit. Boston: Courier Corporation. Koellinger, P., Minniti, M., \& Schade, C. (2007). "I think I can, I think I can": Overconfidence and entrepreneurial behavior. Journal of Economic Psychology, 28(4), 502-527. https://doi.org/10.1016/j.joep.2006.11.002 Landman, J., Vandewater, E. A., Stewart, A. J., \& Malley, J. E. (1995). Missed opportunities: Psychological ramifications of counterfactual thought in midlife women. Journal of Adult Development, 2(2), 87-97. https://doi. org/10.1007/BF02251257

Lawrence, P. R., \& Lorsch, J. W. (1986). Organization and environment: Managing differentiation and integration (Harvard Business School Classics).

Makridakis, S. G., Hogarth, R. M., \& Gaba, A. (2010). Why forecasts fail. What to do instead. MIT Sloan Management Review, 51(2), 83-90. https://doi. org/10.1038/35037613 
McClelland, D. C. (1987). Characteristics of successful entrepreneurs. The Journal of Creative Behavior, 21(3), 219-233. https://doi. org/10.1002/j.2162-6057.1987.tb00479.x

McKelvie, A., Haynie, J. M., \& Gustavsson, V. (2011). Unpacking the uncertainty construct: Implications for entrepreneurial action. Journal of Business Venturing, 26(3), 273-292. https://doi.org/10.1016/j. jbusvent.2009.10.004

McMullen, J. S., \& Shepherd, D. A. (2006). Entrepreneurial action and the role of uncertainty in the theory of the entrepreneur. Academy of Management Review, 31(1), 132-152. https://doi.org/10.5465/amr.2006.19379628

Mensah E.K. (2019). Robust optimization in data envelopment analysis: Extended theory and applications (Doctoral thesis, Università degli Studi dell'Insubria).

Miller, K. D. (2007). risk and rationality in entrepreneurial processes. Strategic Entrepreneurship Journal, 1, 57-74. https://doi.org/10.1002/sej

Milliken, F. J. (1987). Three types of perceived uncertainty about the environment: State, effect, and response uncertainty. Academy of Management Review, 12(1), 133-143. https://doi.org/10.5465/ amr.1987.4306502

Mitchell, R. K., Busenitz, L., Lant, T., McDougall, P. P., Morse, E. A., \& Smith, J. B. (2002). Toward a theory of entrepreneurial cognition: Rethinking the people side of entrepreneurship research. Entrepreneurship Theory and Practice, 27(2), 93-104.

Mokhtarzadeh, N., Amoozad Mahdiraji, H., Jafari-Sadeghi, V., Soltani, A., \& Abbasi Kamardi, A. (2020). A product-technology portfolio alignment approach for food industry: A multi-criteria decision making with z-numbers. British Food Journal. 122(12), 3947-3967. https://doi. org/10.1108/BFJ-02-2020-0115

Moscati, I., \& Tubaro, P. (2011). Becker random behavior and the asif defense of rational choice theory in demand analysis. Journal of Economic Methodology, 18(2), 107-128. https://doi.org/10.1080/1350 178X.2011.579147

Murnieks, C. Y., Sudek, R., \& Wiltbank, R. (2015). The role of personality in angel investing. International Journal of Entrepreneurship and Innovation, 16(1), 19-31. https://doi.org/10.5367/ijei.2015.0171

Nawaz, M., Abbas Bhatti, G., Ahmad, S., \& Ahmed, Z. (2018). How can the organizational commitment of Pakistan railways' employees be improved? The moderating role of psychological capital. Journal of Entrepreneurship, Management and Innovation, 14(1), 123-142. https:// doi.org/10.7341/20181417

Neumann, J. von, \& Morgenstern, O. (1944). Theory of Gamesand Economic Behavior. Princeton: Princeton University Press.

$\mathrm{Ng}$, D. (2015). Entrepreneurial overconfidence and ambiguity aversion: Dealing with the devil you know, than the devil you don't know. Technology Analysis \& Strategic Management, 27(8), 946-959. 
Nicolaou, N., \& Shane, S. (2010). Entrepreneurship and occupational choice: Genetic and environmental influences. Journal of Economic Behavior and Organization, 76(1), 3-14. https://doi.org/10.1016/j.jebo.2010.02.009

Nielsen, S. L., \& Lassen, A. H. (2012). Identity in entrepreneurship effectuation theory: A supplementary framework. International Entrepreneurship and Management Journal, 8(3), 373-389.

Petrakis, P. E., \& Konstantakopoulou, D. P. (2015). Entrepreneurship under Uncertainty. In Uncertainty in Entrepreneurial Decision Making (pp. 5974). Retrieved from https://doi.org/10.1057/9781137460790_5

Perry, J. T., Chandler, G. N., \& Markova, G. (2012). Entrepreneurial effectuation: A review and suggestions for future research. Entrepreneurship Theory and Practice, 36(4), 837-861.

Rammstedt, B., Danner, D., \& Martin, S. (2016). The association between personality and cognitive ability: Going beyond simple effects. Journal of Research in Personality, 62, 39-44. https://doi.org/10.1016/j. jrp.2016.03.005

Rauch, A., \& Frese, M. (2007). Born to be an entrepreneur? Revisiting the personality approach to entrepreneurship. In The Psychology of Entrepreneurship (pp. 41-65). Retrieved from https://doi.org/10.1016/j. ijrobp.2005.12.005

Read, S., Song, M., \& Smit, W. (2009). A meta-analytic review of effectuation and venture performance. Journal of Business Venturing, 24(6), 573587. https://doi.org/10.1016/j.jbusvent.2008.02.005

Rezaei, M., Jafari-Sadeghi, V., \& Bresciani, S. (2020). What drives the process of knowledge management in a cross-cultural setting: The impact of social capital. European Business Review, 32(3), 485-511. https://doi. org/10.1108/EBR-06-2019-0127

Roese, N. J. (1997). Counterfactual thinking. Psychological Bulletin, 121(1), 133-148. https://doi.org/10.1037/0033-2909.121.1.133

Rotter, J. B. (1990). Internal versus external control of reinforcement: A case history of a variable. American Psychologist, 45(4), 489-493. https://doi. org/10.1037/0003-066X.45.4.489

Sadeghi, V. J., \& Biancone, P. Pietro. (2017a). Exploring the drivers of gender entrepreneurship: Focus on the motivational perspectives in USA, Italy and France. In V. Ratten, V. Ramadani, L.-P. Dana, R. D. Hisrich, \& J. Ferreira (Eds.), Gender and Family Entrepreneurship (pp. 124-141). New York: Routledge Taylor \& Francis Group.

Sadeghi, V. J., \& Biancone, P. Pietro. (2017b). How micro, small and mediumsized enterprises are driven outward the superior international trade performance? A multidimensional study on Italian food sector. Research in International Business and Finance, 45(August 2016), 597-606. https://doi.org/10.1016/j.ribaf.2017.07.136

Sadeghi, V. J., Biancone, P. Pietro, Giacoma, C., \& Secinaro, S. (2018). How does export compliance influence the internationalization of firms: Is it 
a thread or an opportunity? Journal of Global Entrepreneurship Research, 8(1), 3. https://doi.org/10.1186/s40497-018-0089-3

Sarasvathy, S. D. (2001). Causation and effectuation: Toward a theoretical shift from economic inevitability to entrepreneurial contingency. Academy of Management Review, 26(2), 243-263. https://doi.org/10.5465/ amr.2001.4378020

Sarasvathy, S. D. (2009). Effectuation: Elements of Entrepreneurial Expertise. Northampton: Edward Elgar Publishing.

Savage, L. J. (1954). The foundations of statistical inference. Methuen. Retrieved from https://errorstatistics.files.wordpress.com/2016/10/ savage-forum-combined-searchable.pdf

Schumpeter, J. A. (1934). The theory of economic development: An inquiry into profits, capital, credit, interest, and the business cycle (1912/1934). Retrieved from https://www.hup.harvard.edu/catalog. php?isbn=9780674879904

Scott, J. (2000). Rational choice theory. In Understanding Contemporary Society: Theories of the Present (p. 129). Retrieved from http://dx.doi. org/10.4135/9781446218310.n9

Shane, S., \& Venkataraman, S. (2000). The promise of entrepreneurship as a field of research. Academy of Management Review, 25(1), 217-226.

Short, J. C., Ketchen, D. J., Shook, C. L., \& Ireland, R. D. (2010). The concept of "opportunity" in entrepreneurship research: Past accomplishments and future challenges. Journal of Management, 36(1), 40-65. https://doi. org/10.1177/0149206309342746

Simon, H. A. (1957). Models of Man; Social and Rational. New York: Wiley.

Simon, M., Houghton, S. M., \& Aquino, K. (2000). Cognitive biases, risk perception, and venture formation: How individuals decide to start companies. Journal of Business Venturing, 15(2), 113-134. https://doi. org/10.1016/S0883-9026(98)00003-2

Smithson, M. (2012). Ignorance and Uncertainty: Emerging Paradigms. Berlin: Springer Science \& Business Media.

Sukumar, A., Jafari-Sadeghi, V., Garcia-Perez, A., \& Dutta, D. K. (2020). The potential link between corporate innovations and corporate competitiveness: Evidence from IT firms in the UK. Journal of Knowledge Management, 24(5), 965-983. https://doi.org/10.1108/JKM-10-2019-0590

Tuten, Tracy L.; Bosnjak, M. (2001). Understanding differences in web usage: The role of need for cognition and the five factor model of personality. Social Behavior and Personality: An International Journal, 29(4), 391-398.

Valliere, D. (2013). Towards a schematic theory of entrepreneurial alertness. Journal of Business Venturing, 28(3), 430-442.

Vealey, R. S. (2001). Understanding and enhancing self-confidence in athletes. Handbook of Sport Psychology, 2, 550-565.

Welter, C., \& Kim, S. (2018). Effectuation under risk and uncertainty: A simulation model. Journal of Business Venturing, 33(1), 100-116. 
Wijbenga, F. H., \& van Witteloostuijn, A. (2007). Entrepreneurial locus of control and competitive strategies - The moderating effect of environmental dynamism. Journal of Economic Psychology, 28(5), 566589. https://doi.org/10.1016/j.joep.2007.04.003

Wiltbank, R., Dew, N., Read, S., \& Sarasvathy, S. D. (2006). What to do next? The case for non-predictive strategy. Strategic Management Journal, 27(10), 981-998.

Yan, J. (2018). The impact of entrepreneurial personality traits on perception of new venture opportunity. New England Journal of Entrepreneurship, 13(2), 21-35. https://doi.org/10.1108/neje-13-02-2010-b002

Zacharakis, A. L., \& Shepherd, D. A. (2001). The nature of information and overconfidence on venture capitalists' decision making. Journal of Business Venturing, 16(4), 311-332. https://doi.org/10.1016/S08839026(99)00052-X

\begin{abstract}
Abstrakt
Cel: Celem tego artykułu jest rozwój literatury przedsiębiorczości poprzez pogłębienie zrozumienia powiq̨zań między zachowaniem a umiejętnościami poznawczymi w procesie podejmowania decyzji w warunkach niepewności. Metodyka: Metoda tego badania została dostosowana do ram stosowanych przez Garrett i Holland (2015), którzy na podstawie narracji koncepcyjnych opracowali propozycje dotyczqce tego, jak niepewność środowiskowa i złożoność w różny sposób wpływajq na motywacje i świadomość niezależnych przedsiębiorców i przedsiębiorców korporacyjnych, aby angażować się w przedsiębiorczość. Wyniki: Wyniki tych badań zapewniajq koncepcyjne podstawy dla szerszej perspektywy zachowań i procesów poznawczych, które motywujq lub utrudniajq działania przedsiębiorcy, a jednocześnie umieszczajq decyzję przedsiębiorcy w centrum teorii decyzji. Implikacje dla teorii i praktyki: Teoretycznie te badania przyczyniajq się do całościowego spojrzenia na decyzje dotyczqce szans. Przekierowujq tradycyjnq ścieżkę analiz decyzji przedsiębiorczych omawianych w sposób odmienny od paradygmatu zachowania lub poznania osobistego, co nie zapewnia pełnego wglqqdu w szersze decyzje przedsiębiorców w warunkach niepewności. W praktyce nasza argumentacja zapewnia dalszy wglqd w czarnq skrzynkę decyzji dotyczqcych możliwości przedsiębiorczych w warunkach niepewności, a tym samym podkreśla potrzebę szerszej perspektywy dla przedsiębiorcy, szczególnie na wczesnym etapie tworzenia przedsięwzięcia, gdzie potrzebne sq pewne cechy poznawcze i wymagane cechy osobowe $w$ harmonii przedsiębiorczości. Oryginalność $\mathrm{i}$ wartość: $B a-$ dania przedsiębiorczości dotyczq̨ce podejmowania decyzji w warunkach niepewności koncentrowały się głównie na wpływie niepewności na działania przedsiębiorcze, podczas gdy próba na poziomie indywidualnym, w szczególności ram poznawczych, ma na celu wyjaśnienie, dlaczego działania się różniq. Podjęto również wysiłki naukowe dotyczqce tego, co wpływa na działania przedsiębiorców z perspektywy osobistych atrybutów przedsiębiorcy. Jednak $w$ literaturze nie proponuje się zintegrowanego podejścia do badania, w jaki sposób umiejętności poznawcze i cechy osobowości wzajemnie się uzupełniajq.
\end{abstract}


Słowa kluczowe: przedsiębiorcza okazja, zdolności poznawcze, cechy osobowości, podejmowanie decyzji w warunkach niepewności, badania przedsiębiorczości

\section{Biographical notes}

Emmanuel Kwasi Mensah is a research data scientist specializing in decision making under uncertainty, data science, data envelopment analysis and operations research. He holds a Ph.D. in methods and models for economic decision from the University of Insubria, Italy. He has several publications in top referred journals to his credit.

Lawrence Adu Asamoah is a Ph.D. candidate at the University of Insubria, Varese, Italy. He also holds an M.Sc./B.A. in Economics from Kwame Nkrumah University of Science and Technology, Kumasi, Ghana. His research interests include poverty and inequality, applied microeconomics, development economics, gender studies, and corporate governance.

Vahid Jafari-Sadeghi, Ph.D., is a Lecturer in Strategy in the School of Strategy and Leadership at Coventry University. Vahid holds his Ph.D. in international entrepreneurship from the University of Turin where he has served as a post-doctoral fellow. Also, he has been a visiting research scholar at the University of Regina and contributed to different research projects with various scholars and universities. Vahid has published papers in several international journals and publications such as Journal of Business Research, International Business Review, Journal of International Entrepreneurship, Research in International Business and Finance, etc. He is member of the editorial advisory board of British Food Journal and has acted as guest editor and reviewer for several academic journals and performed as track chair and presenter for a number of international conferences.

\section{Conflicts of interest}

The authors declare no conflict of interest.

\section{Citation (APA Style)}

Mensah, E.K., Asamoah, L.A., \& Jafari-Sadeghi,V. (2021). Entrepreneurial opportunity decisions under uncertainty: Recognizing the complementing role of personality traits and cognitive skills. Journal of Entrepreneurship, ManagementandInnovation,17(1),25-55.https://doi.org/10.7341/20211711 